\title{
Effect of Phosphorus Fertilizers on Growth and Physiological Phosphorus Use Efficiency of Three Soy Bean Cultivars
}

\author{
Dalshad, A. Darwesh ${ }^{1}$ Pakhshan, M. Maulood ${ }^{2}$ and Shireen A. Amin ${ }^{3}$. \\ ${ }^{I}$ Environmental Science Dept. College of Science, University of Salahaddin-Hawler, Iraq \\ ${ }^{2,3}$ Biology Dept., College of Science, University of Salahaddin-Hawler, Iraq
}

\begin{abstract}
A pot experiment was conducted to study the effect of difference phosphorus fertilizers on growth and nutrient status of soya bean cultivars. The treatments including, three cultivars of soybean $(C l=4.7, C 2=43355$, $C 3=44 N K)$, the phosphorus fertilizers including $(P 1=$ Control no fertilizer, $P 2=$ Triple super phosphate, $P 3=D i$ ammonium phosphate, $P 4=D i$ potassium phosphate, $P 5=N P K$ 20:20:20 with some trace elements and $P 6=N P K$ 12:36:12 with $\mathrm{Mg}$ ) each of them applied in $75 \mathrm{Kg} \mathrm{P.ha}^{-1}$. The factorial experiment was laid out in a complete randomized design (CRD) with three replicates. The results indicates that the highest values (23.47 g.pot ${ }^{-1} 12.07$

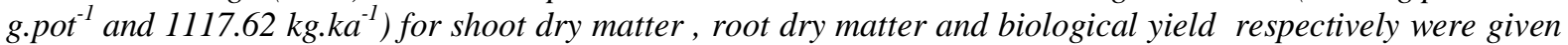
by the application superphosphate fertilizers in the cultivar $44 N K$ followed by the cultivars 4.7 and 43355 which treated by the PK and NPK (12:36:12) Mg respectively. However the result revealed that the increase in uptake of $P$ with the application of phosphorus over control was $280.49 \%$ in case of $44 N K$ cultivar, $255.01 \%$ in case of 4.7 cultivar and $99.75 \%$ in case of 43355 cultivar. The high values of PUEp (55.556\%) and PFE (10.079\%) were recorded by the application of superphosphate in 44NK cultivars, while the low values were $(4.622 \%$ and $0.392 \%)$ over control recorded by the application of NPK(20:20:20) trace elements and super phosphate in case of 4.7 and 43355 cultivars respectively.
\end{abstract}

Keywords: DAP, nutrient status, phosphorus fertilizers, Phosphorus use efficiency, Soybean.

\section{Introduction}

Soy bean is one of the most important legume crops for human nutrition and has been traditionally cultivated in calcareous soils in arid and semi-arid regions; the agronomical importance of soybean (Glycine max L.) is linked to its high protein content (25\%-29\%) [1], Soybean seed is a source of protein and oil for human nutrition and a source of soybean meal for livestock feed. Soybean protein meal and soybean oil accounted for 69\% and 30\%, respectively in 2006 and 2007, of the world's supply of protein meal and edible oil. Many international and domestic soybean processors prefer soybean with at least $340 \mathrm{~g} \mathrm{~kg}^{-1}$ protein and $190 \mathrm{~g}$ $\mathrm{kg}$ oil, assuming $130 \mathrm{~g} \mathrm{~kg}^{-1}$ seed moisture Soybean seed quality is determined by the quantity and quality of protein and oil content seed composition[2]. A study was conducted in the wet season by [3] to evaluate the effect of phosphorus on the growth and yield of two cowpea varieties sourced from republic of Niger. They results showed significant response to applied $\mathrm{P}$ on pods per plant, grain and yield and 100 -seed weight with highest response to the application of $60 \mathrm{~kg} \mathrm{P}$ ha. An experiment was conducted by [4] to study the combination effect of fertilizer sources (Triple superphosphate TSP and Rock phosphate) and their concentration $(0,18.75$, $\left.37.5,75 \mathrm{bkg} \mathrm{P}_{2} \mathrm{O}_{5} / \mathrm{ha}\right)$ and $(1250$ and $2500 \mathrm{~kg} / \mathrm{ha})$ on crop yields in rice-soybean double cropping. The analysis of data revealed that plots which treated with rock phosphate recorded the maximum grain yield. [5] studied the effect of three levels of phosphorus fertilizer $(10,20,30) \mathrm{kg} \mathrm{P} \mathrm{ha}^{-1}$ on soy bean grain yield ,the result showed that the phosphorus fertilization significantly increment soybean grain yield the average yield responses to phosphorus varied from $87 \mathrm{~kg} \cdot \mathrm{ha}^{-1}\left(\mathrm{P}_{10}\right)$ to $217 \mathrm{~kg} \cdot \mathrm{ha}^{-1}\left(\mathrm{P}_{30}\right)$. [6] indicated that the application of different levels of phosphorus $\left(30,60,90\right.$ and $\left.120 \mathrm{~kg} \mathrm{P}_{2} \mathrm{O}_{5} \cdot \mathrm{ha}^{-1}\right)$ caused a significant increase of growth and yield parameters of soybean. The results of study revealed that application $120 \mathrm{~kg}^{-} \mathrm{ha}^{-1}$ phosphate gave higher seed yield (1955.56 $\mathrm{kg} \cdot \mathrm{ha}^{-1}$ ) compared to control $\left(1274.07 \mathrm{~kg} \cdot \mathrm{ha}^{-1}\right)$, also the result of same study show plant height was significantly affected by phosphorus application. The maximum plant height $(56.2 \mathrm{~cm})$ was recorded in case of application $\left(120 \mathrm{~kg} \mathrm{P}_{2} \mathrm{O}_{5} \cdot \mathrm{ha}^{-1}\right)$, while the minimum plant height $(49.37 \mathrm{~cm})$ was observed in control, however, in the absence of a proper crop variety and fertilizer inputs, the yields are low in alkaline soils. The applied $\mathrm{P}$ gets fixed immediately after application in calcareous soils and the availability to the crop is poor. Genotypic differences for better growth under alkaline conditions have been demonstrated because genetic effects modifying tolerance to alkaline are heritable. The soybean has been reported to $\mathrm{P}$ fertilizers differently in alkaline soils depending on the $\mathrm{pH}$, soil fertility and the nature of genotype [7] and [8]. It has been reported that imbalanced and inadequate nutrition results in poor yields of soybean [9]. The investigation was undertaken to study the performance of different soybean cultivars with different levels of applied P fertilizer. Due to fixation of applied $\mathrm{P}$ in Alkali soils, higher dose of the nutrient are required to satisfy the fixation needs and the 
requirement of the crop. The alkali soils are generally poor in fertility and require optimum dose of nutrients for higher productivity. In many agriculture production systems, phosphorus has been identified as the most efficient essential nutrient after nitrogen. The calcareous soil are wide spread throughout the world involved Kurdistan region soils, thus the availability of phosphorus in these soil is low due to the high calcium carbonate $\left(\mathrm{CaCO}_{3}\right)$ content which led to chemical fixation of phosphorus. However, the studies on effect of different phosphorus fertilizers on soybean in Kurdistan region are very rare, thus the objectives of this study are to determine the effect of various sources of phosphorus fertilizers on growth, physiological phosphorus use efficiency and phosphorus fertilizers efficiency of different soybean cultivars.

\section{Materials And Methods}

The Research Was Conducted In The Green House of College of Science, University of Salahaddin /Erbil. The experiment was a factorial on the basis of completely randomized design including two factors and three replication. The first factors involved Three varieties of soybean $\left(C_{1}=4.7, C_{2}=43355, C_{3}=44 N K\right)$, while the second factors were the six phosphorus fertilizers including $\left(\mathrm{P}_{1}=\right.$ as control, $\mathrm{P}_{2}=$ Triple super phosphate, $\mathrm{P}_{3}=$ Di ammonium phosphate, $\mathrm{P}_{4}=$ Di potassium phosphate, $\mathrm{P}_{5}=$ bNPK 20:20:20 with some trace elements and $\mathrm{P}_{6}=$ bNPK 12:36:12 with Mg) ) each of them applied in $75 \mathrm{Kg} \mathrm{P} \mathrm{ha}^{-1}$ ) on growth, nutrient status in soybean, Hence 18 experimental treatments were tested in each replicates making the total of 54 pots .The soil was dispensed in to plastic pots ( $7 \mathrm{~kg}$ soil per pots ) the sterilized soy bean seeds (4seeds) were planted in each pots after germination thinned to 2plants. Plant irrigated with tap water to maintain soil moisture near field capacity. At harvest the plants were cut at soil surface from each pot, placing in weighted bag oven dried at $65^{\circ} \mathrm{C}$ for 48 hours and after that immediately the dry weight was obtained. Plant samples after weighting were grinding with stainless steel mill, and stored for chemical analysis. Plant samples were digested according to [10] by using (1:1concentrated $\mathrm{H}_{2} \mathrm{SO}_{4}$ and $\mathrm{H}_{2} \mathrm{O}_{2}$ ). The $\mathrm{N}$ content was measured by the micro-Kjeldahl digestion method of [11]. The $\mathrm{P}$ content was determined by the molybdenum blue colorimetric method of [12], the flame photometric method of [13].was used to determined K. Two component of phosphorus use efficiency were determined, the phosphorus fertilizers efficiency PFE and physiological phosphorus use efficiency were calculate using the formula used by [14].

\subsection{SOIL PROPERTIES}

Some physical and chemical characteristics of the soil under study were as follows: texture: sandy loam; $\mathrm{CaCO}_{3} 150$ g. $\mathrm{kg}^{-1}$; $\mathrm{pH}$ (saturated paste) 7.7; EC $0.6 \mathrm{dS} . \mathrm{m}^{-1}$; Organic matter $1.7 \mathrm{gm}_{\mathrm{Kg}} \mathrm{Kg}^{-1}, \mathrm{NH}_{4} \mathrm{OAc}^{-}$ extractable K 1.49 meq. $100 \mathrm{~g}^{-1}$; exchangeable Ca 11.0 meq. $100 \mathrm{~g}^{-1}$; $\mathrm{Mg} 5$ meq. $100 \mathrm{~g}^{-1}$; total N $0.44 \mathrm{mg} \mathrm{kg}^{-1}$; and $\mathrm{NaHCO}_{3}$ - extractable P $3.6 \mathrm{mg} . \mathrm{kg}^{-1}$, respectively. Chemical soil analysis was conducted as described in [15].

\subsection{STTISTICAL ANALYSIS}

The experiment was designed in completely randomized design with 3 replications (factorial CRD). The experimental data were analyzed by ANOVA and differences between the treatment means were separated by LSD test [16].

\subsection{YIELD COMPONENT}

\section{Results And Discussion}

The data present in Table 1 indicate that shoot dry matter, root dry matter and biological yield of soybean cultivars were significantly affected by the application of different source of phosphorus fertilizers, the highest values (23.47 g.pot ${ }^{-1} 12.07$ g.pot ${ }^{-1}$ and $1117.62 \mathrm{~kg} \cdot \mathrm{ka}^{-1}$ ) for shoot dry matter, root dry matter and biological yield respectively were given by the application superphosphate fertilizers in the cultivar 44 NK followed by the cultivars 4.7 and 43355 which treated by the PK and NPK (12:36:12) Mg respectively. This result could be explained on the ground that the super phosphate as source of phosphorus fertilizer is a low release fertilizers in addition to its high phosphorus content $23 \%$ and about $95 \%$ of which is water soluble and nearly all of which classed as available, however the application of phosphorus fertilizers to soil improve the root growth, then enhancing the shoot growth subsequently increase the yield component of the crop [17 and $18]$.

\subsection{NUTRIENT CONTENT}

Table (1) shows that the combination between cultivars and phosphorus fertilizers affected significantly $(\mathrm{P} \leq 0.05)$ the protein, nitrogen, potassium and phosphorus concentration, the data revealed that the highest mean values $\left(162.38,25.98,2.47 \mathrm{mg} . \mathrm{g}^{-1}\right),\left(23.91 \mathrm{mg} . \mathrm{g}^{-1}\right.$ ) of (protein, nitrogen, phosphorus), (potassium) were recorded in cultivar 44NK which received super phosphate and DAP respectively. This result could be explained on the ground that the addition of convenient source of phosphorus fertilizer increase the nutrient 
content of plant, via enhancing the root growth and increasing the root hair length, beside increase the root surface area, and the DAP is water soluble and it is an acid soil forming fertilizer. This result and explanation partially agreed with those recorded by [19]. However the present result confirm that soybean largely depending on the source of phosphorus fertilizer for obtain the nutrient particularly phosphorus and nitrogen to achievement the normal growth under normal soil nutrient condition, the increased concentration of $\mathrm{P}$ in plant paralleled the increase in plant dry matter production, suggesting that $\mathrm{P}$ was element limiting soybean growth .

Table (1) Effect of phosphorus fertilizers on growth, protein and nutrients content in three soybean cultivars

\begin{tabular}{|c|c|c|c|c|c|c|c|c|}
\hline $\begin{array}{l}\text { Treatment } \\
\mathrm{s}\end{array}$ & $\begin{array}{l}\text { Shoot } \\
\text { Dry } \\
\text { weight } \\
\left(\mathrm{g} \cdot \text { pot }^{-1}\right)\end{array}$ & $\begin{array}{l}\text { Root } \\
\text { Dry } \\
\text { weight } \\
\text { (g.pot } \\
\begin{array}{c}1^{-} \\
\text {) }\end{array}\end{array}$ & $\begin{array}{l}\text { Biologic } \\
\text { al yield } \\
\text { kg.ha }^{-1}\end{array}$ & $\begin{array}{l}\text { Protein } \\
\left(\mathrm{mg}^{\left.-g^{-1}\right)}\right.\end{array}$ & $\begin{array}{l}\text { Nitrogen } \\
\left(\mathrm{mg}^{-g^{-1}}\right)\end{array}$ & $\begin{array}{l}\text { Potassium } \\
\left(\mathrm{mg}^{-g^{-1}}\right)\end{array}$ & $\begin{array}{l}\text { Phosphorus } \\
\quad\left(\mathrm{mg} \cdot \mathrm{g}^{-1}\right)\end{array}$ & $\begin{array}{l}\text { Increase } \\
\text { P uptake } \\
\%\end{array}$ \\
\hline $\mathrm{P}_{1} \mathrm{C}_{1}$ & 9.81 & 2.17 & 467.10 & 25.62 & 4.10 & 13.55 & 1.26 & - \\
\hline $\mathrm{P}_{1} \mathrm{C}_{2}$ & 8.35 & 2.36 & 397.71 & 18.75 & 3.01 & 10.20 & 2.22 & - \\
\hline $\mathrm{P}_{1} \mathrm{C}_{3}$ & 8.77 & 3.57 & 417.86 & 21.87 & 3.50 & 20.38 & 1.72 & - \\
\hline $\mathrm{P}_{2} \mathrm{C}_{1}$ & 16.95 & 3.13 & 807.05 & 43.28 & 6.93 & 15.09 & 1.80 & 147.33 \\
\hline $\mathrm{P}_{2} \mathrm{C}_{2}$ & 9.09 & 2.17 & 432.81 & 59.62 & 9.54 & 15.32 & 2.24 & 8.63 \\
\hline $\mathrm{P}_{2} \mathrm{C}_{3}$ & 23.47 & 12.07 & 1117.62 & 162.38 & 25.98 & 22.77 & 2.47 & 280.49 \\
\hline $\mathrm{P}_{3} \mathrm{C}_{1}$ & 14.25 & 4.68 & 678.57 & 69.82 & 11.17 & 11.72 & 2.31 & 159.94 \\
\hline $\mathrm{P}_{3} \mathrm{C}_{2}$ & 12.78 & 6.08 & 608.67 & 82.07 & 13.13 & 21.29 & 2.30 & 60.00 \\
\hline $\mathrm{P}_{3} \mathrm{C}_{3}$ & 13.79 & 6.07 & 656.57 & 114.74 & 18.36 & 23.91 & 2.45 & 125.05 \\
\hline $\mathrm{P}_{4} \mathrm{C}_{1}$ & 22.10 & 10.66 & 1052.18 & 140.25 & 22.44 & 20.04 & 1.99 & 255.01 \\
\hline $\mathrm{P}_{4} \mathrm{C}_{2}$ & 12.80 & 5.14 & 609.38 & 80.44 & 12.87 & 12.61 & 1.80 & 23.94 \\
\hline $\mathrm{P}_{4} \mathrm{C}_{3}$ & 22.26 & 8.00 & 1060.10 & 85.75 & 13.72 & 17.91 & 2.25 & 239.02 \\
\hline $\mathrm{P}_{5} \mathrm{C}_{1}$ & 12.58 & 3.81 & 599.19 & 75.54 & 12.09 & 19.08 & 2.41 & 159.77 \\
\hline $\mathrm{P}_{5} \mathrm{C}_{2}$ & 12.15 & 3.60 & $\mathbf{5 7 8 . 5 7}$ & 75.95 & 12.15 & 12.74 & 2.34 & 46.04 \\
\hline $\mathrm{P}_{5} \mathrm{C}_{3}$ & 13.17 & 4.22 & 627.10 & 61.25 & 9.80 & 11.17 & 2.05 & 76.07 \\
\hline $\mathrm{P}_{6} \mathrm{C}_{1}$ & 11.33 & 3.03 & 539.33 & 58.39 & 9.34 & 11.53 & 1.68 & 53.80 \\
\hline $\mathrm{P}_{6} \mathrm{C}_{2}$ & 14.57 & 4.85 & 693.71 & 100.86 & 16.14 & 15.76 & 2.43 & 99.57 \\
\hline $\mathrm{P}_{6} \mathrm{C}_{3}$ & 21.13 & 9.77 & 1006.10 & 39.20 & 6.27 & 15.95 & 2.20 & 202.50 \\
\hline LSD 5\% & 6.37 & 3.36 & 303.12 & 13.12 & 2.10 & 6.05 & 0.46 & \\
\hline
\end{tabular}

\subsection{TOTAL PHOSPHORUS UPTAKE}

Data on P uptake in Table (1) and Fig. (1) reveal that phosphorus uptake was significantly affected by the use of $\mathrm{P}$ fertilizers source and soybean cultivars, the high mean value of $\mathrm{P}$ uptake recorded in $44 \mathrm{NK}$ cultivar that treated by superphosphate which attained ( $57.72 \mathrm{mg} \cdot \mathrm{pot}^{-1}$ ), followed by 4.7 and 43355 cultivars. The uptake of nutrients was significantly related to the total biomass produced by a cultivar, the increase in uptake of $\mathrm{P}$ with the application of phosphorus over control was $280.49 \%$ in case of $44 \mathrm{NK}$ cultivar, $255.01 \%$ in case of 4.7 cultivar and $99.75 \%$ in case of 43355 cultivar. This showed that the application of $\mathrm{P}$ to soybean improved the efficiency of cultivars in accumulating more P, N and K. Superphosphate was found to be the superior source followed by DAP and less effective was NPK (20:20:20) trace elements. This crop to phosphorus application and has preference for P more in the form water soluble than in other form [20].

\subsection{PHOSPHORUS EFFICIENCY}

The physiological phosphorus use efficiency (PUEp) and phosphorus fertilizers efficiency (PFE) of three soybean cultivars were calculated for different phosphorus fertilizers are present in Fig. (1and 2) respectively. The results of PUEp and PFE demonstrated the superiority of superphosphate fertilizer over the other sources of P fertilizer in case the 44NK soybean cultivars. The application of superphosphate resulted in improved the PUEp in case 44NK cultivars followed by the application of NPK (12:36:12) Mg and supper phosphate in case of 43355 cultivars respectively, on the other hand the application superphosphate improved the PFE in case of 44NK cultivars followed by the application of NPK (12:36:12) Mg and PK in the same cultivars, thus the high mean values of PUEp (55.556\%) and PFE(10.079\%) were recorded by the application of superphosphate in 44NK cultivars, while the low mean values were $(4.622 \%$ and $0.392 \%)$ over control recorded by the application of NPK (20:20:20) trace elements and super phosphate in case of 4.7 and 43355 cultivars respectively, in general the $44 \mathrm{NK}$ cultivars proved superior to 4.7 and 43355 cultivars in these two parameters. The differential response of cultivars to phosphorus fertilizers is may be due to their inherent indeterminate 
growth habitat and thereby efficiency in utilizing available and reserve nutrient resources, in addition to the behavior of phosphorus fertilizes and their physico-chemical properties. These results agree with those reported by [21].

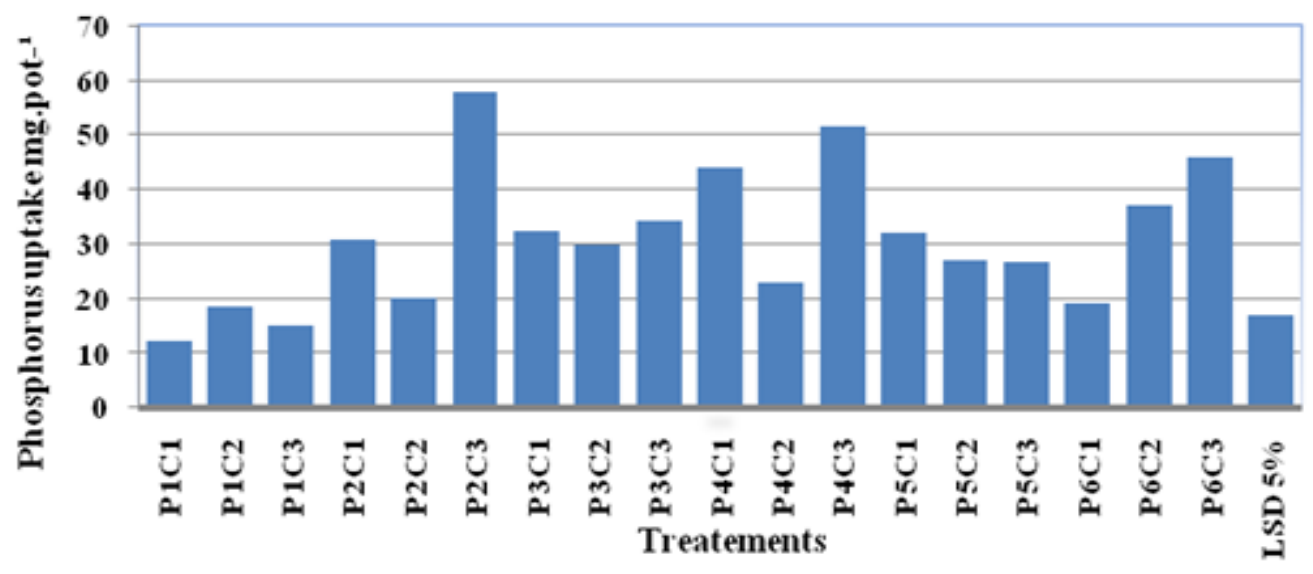

Figure (1) Effect of phosphorus fertilizers on phosphorus uptake by soybean cultivares
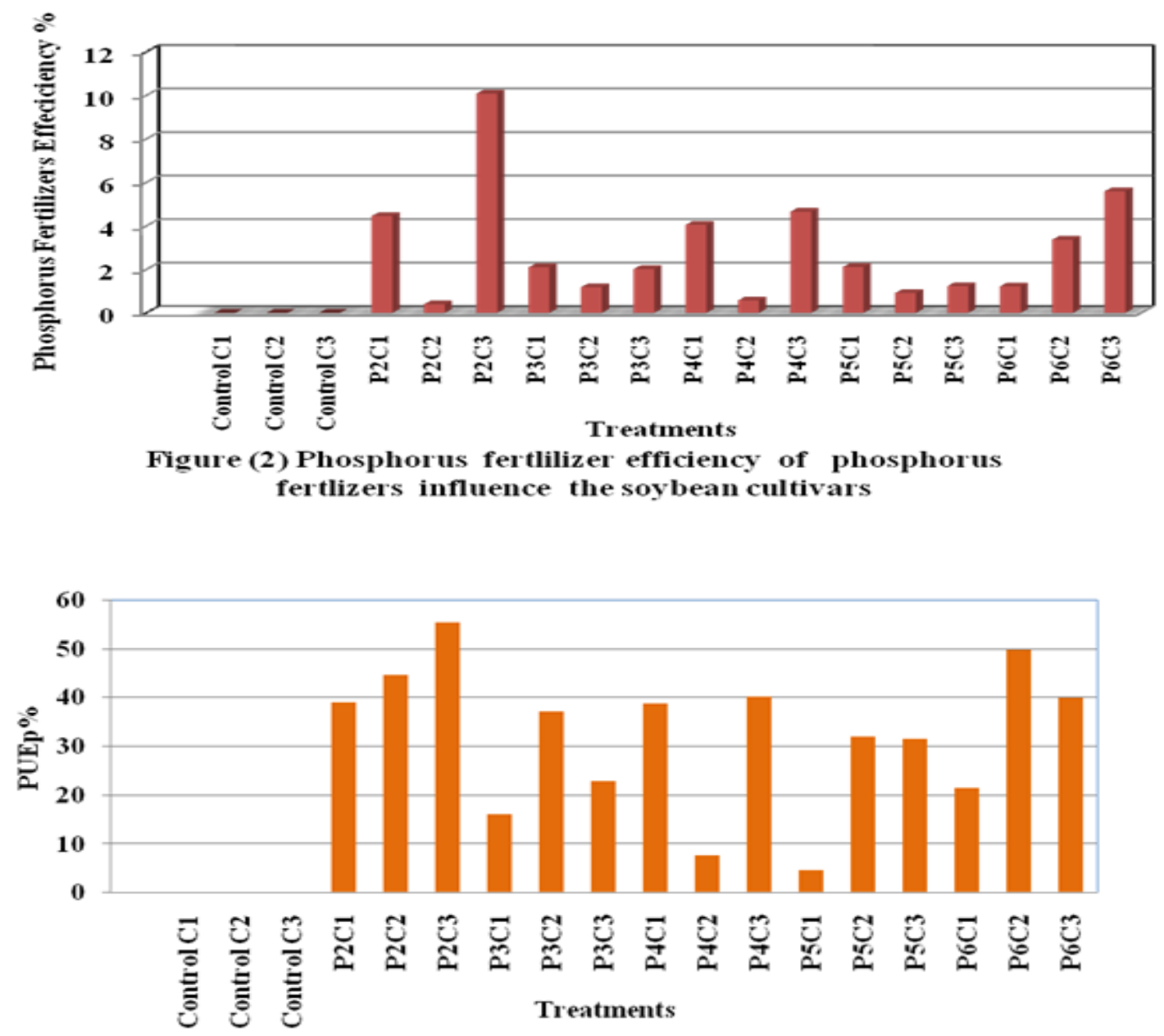

Figure (3) Physiological phosphorus use effeciency (PUEp) of soybean cultivars affected by phosphorus fertlizers 


\section{Conclusion}

The experimental results showed that the application superphosphate fertilizers to the cultivar $44 \mathrm{NK}$ gives high shoot dry matter, root dry matter and biological yield, however the result indicate the highest mean values of protein, nitrogen, phosphorus, (potassium) were recorded in cultivar 44NK which received super phosphate and DAP respectively. At the same time the application super phosphate to soybean cultvaries increment the phosphorus uptake.

\section{References}

[1] C. Hamel, B.V. Furlan and D.L. Smith, $\mathrm{N}_{2}$-Fixation and transfer in a field grown mycorrhizal corn and soybean intercrop, Plant and Soil, 133, 1991, 177-185.

[2] B. Nacer, and A. M. Gillen, Soybean seed protein, oil, fatty acids, N, and S partitioning as affected by node position and cultivar, Agricultural Sciences, 1(3), 2010, 110-118.

[3] A. Singh, A.L. Baoule, H. G. Ahmed, A.U. Dikko, U. Aliyu, M.B. Sokoto, M.Musa, B. Haliru, J. Alhassan, Influence of phosphorus on the performance of cowpea (Vigna unguiculata (L) Walp.) varieties in the Sudan savanna of Nigeria, Agricultural Sciences, 2(3), 2011, 313-317

[4] C. Suwannarat, and W. Wajananawat, Effects of sources of phosphorus fertilizer on crop yields in rice-soybean double cropping. Kaset sart Journal (National sciences), 21, 1984, 93-101.

[5] P. Barbagelata, R. Melchiori and O. Paparotti, Phosphorus fertilization of soybeans in clay soils of Entre Rios Province. Better Crops International Journal, 16(1), 2002.

[6] M.A. Malik, M. A. Cheema, H. Z. Khan and M.A. Wahid, Gowth and yield response of soybean(Glycine max L.) to seed inoculation and varying phosphorus levels. Journal Agriculture. Research, 44 (1), 2006, 47-54.

[7] U.C. Sharma and B. Singh, Effect of Applied P on the Yield and Incidence of Pod Blight of Soybean in Nagaland. Journal of Hill Research, Vol. 4, 1991, 94-96.

[8] R. Sandeep, S. Joseph and M. S. Jisha, "Yiel and Nutrient Uptake of Soybean as Influenced by Phosphate Solubilising Microorganisms," World Journal of Agricultural Sciences, Vol. 4, 2008, 835-838.

[9] F. G. Boswell and O. E Anderson, "Long Term Residual Fertility and Current NPK Application Effects on Soybean," Agronomy Journal, 68(2), 1976, 642-645.

[10] A.A.M. Schuffelen and J.G.H. Vanschaunouwenburg, Quick testes for soil and plant analysis used by small laboratories, Netherland Journal of Agriculture Science, 9, 1961, 2-16.

[11] J.M. Bremner and C.S. Mulvaney, Methods of Soil Analysis, Part 2, Agronomy Vol. 9, $2^{\text {nd }}$ Edition, American Journal of Soil Science, Society, Madison WI,1982, 595-624.

[12] Black,C.A., Method of soil analysis, (Maddison, Wisconson: American Society Agriculture Inc, 1965).

[13] S.E. Allen, Chemical analysis of ecological materials, (Osney Mead, Oxford: Black well Scientific Publications, 1976).

[14] M.J. Muhammad and H.I. Malakawi, Root and shoot nutrient acquisition response of mycorrhiza and non-mycorrhizal wheat to phosphorus application to highly Calcareous soils, 2004.

[15] M. Pansu and J. Gautheyrou, Hand book of soil analysis, (Berlin Heidelberg: Springer-Verlag, 2006).

[16] R.G. Steele and J.H.Torrie, Principle and procedure of statistic, (New York: McGraw Hill Book Co.Inc, 1969).

[17] Y.O. Samia, W.M.A. Ahmed and A. A. Mariod, Effect of Urea, NPK and Compost on Growth and Yield of Soybean (Glycine max L.), in Semi-Arid Region of Sudan ISRN Agronomy Volume $2012,2012$.

[18] M.M. Pauline, J.B.O. Ogola, J.J.O. Odhiambo, A. Whitbread and J. Hargreaves, Effect of phosphorus fertilizers rate on growth an yield of three soybean (Glycine $\max$ L.) cultivars in Limpopo province, (2010).

[19] S.H. Jabaji-Hare and W.B. Kendrick, Response of an endomycorrhizal fungus in Allium porrumL. To different concentrations of the systemstic fuingicides metalaxyln (Ridomil ) and Fosetyl-Al (Aliette), Soil Biological Biochemistry, 19, 1987, 95-99

[20] K.K. Mustafa, D.A. Darwesh and A.A. Luay, Effect of mycorrhiza ,phosphorus and urea on ammonia volatilization and soybean growth. Journal Dohuk University, 7(2), 2004, 101-105.

[21] U. C. Sharma, M. Datta and V. Sharma, Effect of Applied Phosphorus on the Yield and Nutrient Uptake by Soybean Cultivars on Acidic Hill Soil, Open Journal of Soil Science, 1, 2011, 45-48 